\title{
Development Predicament and Exploration of International Exchanges and Cooperation Among Universities of Finance and Economics
}

\author{
Wang XI \\ Office of International Exchange and Cooperation, Tianjin University of Finance and Economics, \\ Tianjin, China \\ Email:345178910@qq.com
}

Keyword: International exchanges and cooperation; public platform; development predicament

\begin{abstract}
The aim of this paper is to explore and solve the problems arising in the process of international exchanges and cooperation among universities of finance and economics. On-the-spot method is adopted in this paper. By collecting the first-hand information from government departments and universities, solutions to these problems are offered. The innovation mainly embodies in adding information sharing mechanism to the building of government-public supporting platform, which helps realize information symmetry among universities and then more effective exchanges and cooperation.
\end{abstract}

\section{Introduction}

In an era of increasing globalization and interdependence, cross-cultural exchanges among countries have been promoted by information sharing on a global scale and the convenience of computer networks. What's more, economic integration has expanded the demand for international talents. So, it is impossible for any country which is separated from the international environment to succeed or sustain its development international environment.

Faced with globalization, it is one of the necessary responses for universities to carry out international exchanges and cooperation which integrates the idea of internationalization and cross-cultural integration into the function of teaching, research, and service in universities.

Financial and economic colleges and universities usually set up majors in economics and management. And such professional students acquire knowledge mostly based on the latest developments and the literatures which are derived from developed countries such as Europe and the United States. What should be pointed out is as the related courses are characterized by rapid updating and most of the classic textbooks and works are written in English, and even English only, it is required for these related majors to be geared to international standards, thus improving the students' ability to get employed and meeting market demand. Nowadays, many colleges and universities have realized the importance of cultivating international talents in finance and economics in order to adapt the finance and economics profession to this status quo and integrate the higher education with internationalization. However, at the same time, some development difficulties have also been encountered in the course of international exchanges and cooperation.

\section{Existing Problems}

\section{Problems on Policies and Regulations}

With an incomplete set of policies and regulations as well as overlapping functions between different departments, many government departments are characterized by low administrative efficiency. Take the establishment of a Chinese-foreign cooperatively-run school for example, it takes a long period of time for universities to obtain approval rights with long checking time and a series of complex course. And this will exactly cause the foreign partner organizations to question our sincerity for cooperation and affect the enthusiasm of both parties to a certain extent. In addition, the procedures for foreign experts to come to China are complex, and the working procedures of the customs, health and quarantine departments are out of touch with the timeliness requirements of international cooperation and exchange. All of these have played a certain "forced" restriction on 
the development of international cooperation and exchange.

\section{Lack of Government-Supported Public Platforms}

Although international exchanges and cooperation of universities in Tianjin have started early and developed rapidly with many achievements, it cannot be ignored that there is a phenomenon of "sweep the snow only in front of your doorstep" which refers to a mentality of every-man-for-himself. As international exchanges and cooperation in colleges and universities lacks a common supporting platform, many of them are often in a relatively closed state in which sources and sharing of information are scarce. Unnecessary duplications of work will surely cause chronic inefficiency. For example, in the process of investigating credit worthiness of a foreign school, much related work has been done repeatedly by different universities because information cannot be shared. It is horribly inefficient.

\section{The Gap between the Level of the Teaching Staff}

Lacking of international talents is also a major bottleneck. Most colleges and universities are unable to provide qualified bilingual teachers. At the same time, with heavy teaching tasks, it is impossible for most of the teachers to devote their time and energy into academic research. As a result, there are fewer teachers who can participate in high-level programs, attend academic conferences which are held internationally or communicate with foreign counterparts academically. The increasing gap between China and abroad in teaching staff and international standards has hindered the further development of international exchange and cooperation in universities.

\section{Development Priorities and Strategic Plans}

Most colleges and universities still lack the overall development plan for international education which includes clear objectives, guarantee measures as well as cooperation and assistance from relevant departments. There are not many universities setting up complete plans among those who have carried out international exchanges and cooperation. And other schools that have indicated that they will explore this field in the future are not even having a serious consideration or a detailed plan.

\section{Solutions to These Problems}

\section{Improving Timeliness and Proactiveness of Policies and Regulations}

For all universities, they need to strengthen their research on international exchanges and cooperation and draw lessons from cities in the United States, Australia, New Zealand, Malaysia, Thailand, and Hong Kong. Besides, in order to find out the present conditions and the problems and keep up with the actual development, it is required for them to do more research and increase the level.

For government departments, they need to figure out what obstacles these colleges and universities have encountered in the course of international exchanges and cooperation. And then by collecting the first-hand information, they need to replace the unscientific and unreasonable provisions with detailed, pertinent, and highly operative regulations so as to make the policies more time-sensitive and forward-looking.

\section{Establishing a Public Service Supporting Platform}

Establishing such a government-supported public platform is conducive to the transparency and openness of information as well as effective communications avoiding duplications among universities. It also plays an important role in promoting fair and open competitions instead of destructive ones. In addition, one of the important responsibilities of this system is to hold occasional symposiums so that all universities have access to sharing much information, learning from each other and promoting common progress.

For government, it will help related departments to receive timely feedback from universities and conduct more complete and systematic plans. These scientific plans and well-designed policies will 
be helpful in meeting the actual development needs, making rational use of quality resources and avoiding duplications of the introduction of projects and courses.

\section{Improving Teacher Training and Management Level}

It's required for all universities to set strict standards which fundamentally guarantees high quality teachers. Rigorous recruitment standards for teachers of Chinese-foreign cooperative education programs must include two parts, namely, the employment standards of domestic teachers and the introduction standards of foreign teachers.

\section{Employment Standards for Domestic Teachers}

For professional teachers, they must have two or more years of experience of teaching in higher vocational colleges or higher educational institutions and gain remarkable effect in education and teaching. Besides, they need to have a certain understanding of Chinese-foreign cooperative education and conduct bilingual teaching.

For teachers who are responsible for practice courses, they must be "double-qualified". Meanwhile, they are also required to have experience working in companies and universities in which they are engaged in educational work for more than two years. If they have gained rich experience and remarkable results in certain companies, it's also possible for them to be employed. On top of that, those who have working experience in Sino-foreign cooperative education institutions, a studying abroad experience or background of international education will be given priority attention.

\section{Employment Standards for foreign Teachers}

Firstly, the foreign teachers introduced must be qualified teachers from cooperative institutions, and there should not be teachers from third party institutions. Secondly, they must be positive, upright, loyal to education, and never disseminate extreme Western culture or have bad political intentions. Thirdly, basic knowledge of Chinese and ability to engage in bilingual teaching are required. On the basis, they should have superb professional qualities as well as abilities in education and teaching, holding senior or higher-level professional titles. Last but not least, they are required to fulfill their teaching tasks in strict accordance with the agreed teaching time and content.

\section{Formulating a Reasonable Strategic Development Plan}

A sound international-oriented development order calls for a scientific plan on institutions. Although it's not easy for us to carry out a layout which stresses the internationalization of high education from the whole, it's possible if local governments devote great energy to strengthening macroscopic planning and then their personal special plans based on the actual conditions of their region.

\section{Research-Based Universities}

They are time-honored provincial universities which are qualified for conferring doctoral degrees. They are mainly focusing on cultivating high-level talents with scientific research and innovation capabilities. They also have their own advantages in various subject areas. Given some supports, they are able to take part in the international teaching and research competition.

\section{Teaching-Based Universities}

Some of them have the right to confer master's degree, the others are emerging provincial universities with doctoral programs with a strong ability of cultivating master students. What they should do is to actively take advantage of their own distinctive disciplines and experience in international exchanges and cooperation, improve their own teaching and research level and then the level of international education. 


\section{Teaching-only Universities}

This kind of universities is mainly built for undergraduates. The disciplines and majors carry very strong practicality and catholicity. So, they are required to put the emphasis on promoting personnel exchanges including sending teachers to learn advanced education ideology and teaching methods, hiring foreign experts and foreign teachers, so as to expand their students' international horizons through the internationalization of the curriculum and improve their overall quality.

In short, all provincially-administrated universities shall give their full play to their advantages according to their personal situation for advancing the scale of international exchanges and cooperation orderly and improving the level of internationalization of higher education.

\section{References}

[1] Yuting Li. The problems and countermeasures of international exchange and cooperation in local colleges and universities. [J]. Journal of Kaifeng Institute of Education., 2016, 36(01):132-133.

[2] Yongling Zheng. The current situation, bottleneck and countermeasure of international exchange and cooperation of local colleges and universities. [J]. Journal of Yanan Institute of Technology, 2012, 26(04):20-22.

[3] Liqin Xu. Systematized research and countermeasures of international exchange and cooperation in colleges and universities. [J].Journal of Zhejiang University of Science and Technology, 2010, 22(05):349-354.

[4]Huanling Zhang, Xia Zhao. Analysis on the current situation of Sino-foreign cooperative education in Beijing. [J]. China Adult Education, 2004, 01:77-78.

[5] Zhenyuan Qu. China education internationalization should pay attention to improve quality. [J]. higher education management, 2015(5):1-4.

[6] Weihong Jiang. Research on the development strategy of Sino-foreign cooperative education in universities of Shandong [D].Jinan: Shandong Economic University, 2010. 